\title{
NEW NAMES FOR NATURAL HYBRIDS IN SARRACENIA
}

LARRY MellichamP • Botanical Gardens • University of North Carolina at Charlotte • 9201 University City Blvd. • Charlotte, North Carolina 28223-0001・USA • tlmellic@ uncc.edu

Keywords: New taxa: Sarracenia $\times$ naczii, Sarracenia $\times$ bellii, Sarracenia $\times$ casei, Sarracenia $\times$ charlesmoorei.

Received: 9 September 2008

Introduction

For the past two years I have been working on my treatment of the family Sarraceniaceae for publication in Volume 8 of the comprehensive Flora of North America, due for publication in 2009. Through my studies, I have come to understand much better two of the current problems in Sarracenia in the Southeastern United States, and have solidified my views. This was done through a combination of examining dried herbarium specimens (representing our preserved knowledge of these plants), comparing specimens grown in a common garden where different plants are grown under almost identical environmental conditions, and seeing the plants in the wild (see Figure 1). These problems involve interpretation of the Sarracenia purpurea and the $S$. rubra complexes. This paper considers natural hybrids involving these taxa.

\section{Sarracenia $\times$ naczii}

As a result of these studies, I now fully recognize the Gulf Coast Sarracenia rosea Naczi, Case \& Case as a valid species (I do not recommend so many authors for a species name!) This species was formerly known as $S$. purpurea subspecies venosa variety burkii Schnell. (Also,

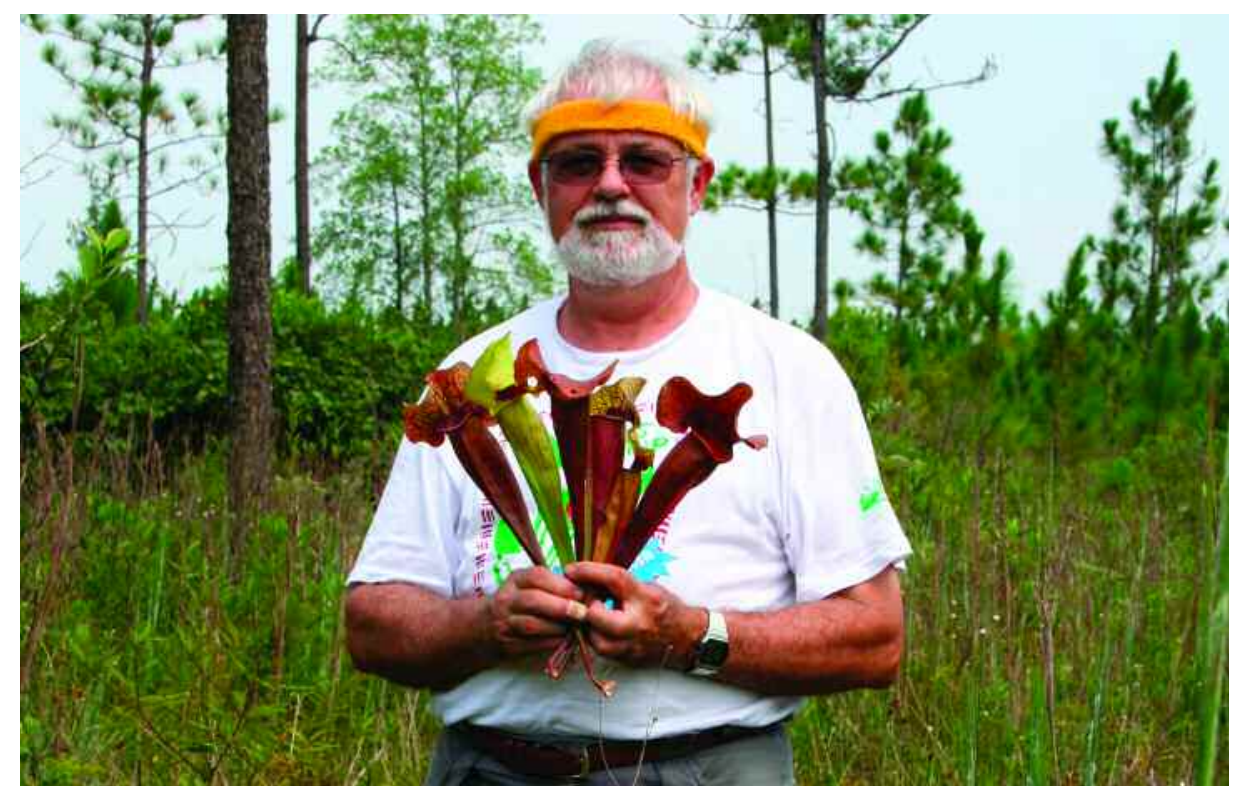

Figure 1: Larry Mellichamp at the type locality for $S . \times$ charlesmoorei, Escambia Co., FL, 3 Sept. 2007. Photo by Stefan Ploszak. 
I do not recommend so many epithets for a taxon!) I also recognize $S$. alabamensis and $S$. jonesii as separate from $S$. rubra. I follow the perspective that Sarracenia rubra subsp. wherryi should be treated as a subspecies of $S$. alabamensis, i.e., S. alabamensis subsp. wherryi.

If you accept $S$. rosea as a separate species, then the hybrids that it forms with other species may be viewed as different taxa than if it were just a subspecies of $S$. purpurea. For example, the well-known wild hybrid Sarracenia $\times$ catesbaei Elliott is a cross between $S$. flava and $S$. purpurea. It was described from a plant collected in Chesterfield County, South Carolina in 1824. This means that one parent was the traditional $S$. purpurea. Sarracenia flava also grows along the Gulf Coast and readily hybridizes with $S$. rosea (which was formerly treated as a variety of S. purpurea). These Gulf Coast hybrids have a different ancestry and can be distinguished from Sarracenia $\times$ catesbaei of the Carolinas. Therefore, I designate a new name for hybrids between S. flava and $S$. rosea.

Sarracenia Xnaczii Mellichamp hybr. nov. (see Figure 2).-TYPE: U.S.A. Florida. Escambia Co.: south side of Ocie Phillips Road, ca. 3 miles east of Perdido River. 3 Sept. 2007. Mellichamp s.n. (HOLOTYPE: UNCC, ISOTYPE: NCU).

Syn.: Sarracenia $\times$ catesbaei sensu Bell non Elliott, J. Elisha Mitchell Sci. Soc. 68: 61. 1952, p.p.

Sarracenia $\times$ naczii, hybrida naturalis nova inter $S$. flava et $S$. rosea, foliis erectis tubulatis e basi ad foramen, luteo-viridis, colore sanguineo ad rubiginoso suffusis vel venosis, $15-50 \mathrm{~cm}$ altis, cucullo cordato undulato, fauce plerumque atrosanguinea, petalis pallide luteo-subroseis. A Sarracenia $\times$ catesbaei statura robustiore, foliis minus incrassatis, ore incrassato differt.

Plants intermediate between the parents, often showing hybrid vigor and making attractive specimens. Pitcher leaves erect, $15-50 \mathrm{~cm}$ tall at maturity, widely tapering from base to orifice, yellowish-green suffused with red or purple and with distinct maroon veins, especially in the upper part of the tube. The hood is large and flamboyant, erect to reflexed forward, broadly cordate, undulate or wavy, rarely not so, often pinched together somewhat in the middle. Often with dark red-purple color in the throat or neck, especially if the $S$. flava parent has this feature. The pitchers are usually finely hairy on the outside surface and the stiff bristles on the inside surface of the hood are usually 0.5-1.2 mm long, coming from the $S$. rosea parent. The flowers are variable, usually pale yellowish with a pink cast (not orange as you might expect from mixing yellow and pink flower colors). In differentiating this hybrid from $S$. ×catesbaei, the Gulf hybrid is more robust and stocky, a bit wider for the height than the Carolina hybrids, with thicker texture. There may also be a noticeably thicker orifice rim as you might expect from the $S$. rosea parent. Because of the great variation in S. flava across the Gulf Coast region, there will be much variance in the expressions of this common hybrid. As usually, there can be backcrossing and introgression with intermediate forms. Knowing where your hybrid comes from also helps to confirm its parentage.

I have named this hybrid in honor of botanist Dr. Robert F. C. Naczi, who painstakingly discerned the characteristics that led to recognizing $S$. rosea as a distinct species.

\section{Sarracenia $\times$ bellii}

In a similar circumstance, the hybrid Sarracenia $\times$ readii Bell was described as a cross between S. leucophylla and S. rubra. However, the type collection was from Washington County, in southwestern Alabama. Therefore, I would recognize today that this $S$. rubra-like parent is really a different species, $S$. alabamensis subspecies wherryi Case \& Case, whose range is from barely in Mississippi across Alabama north of Mobile Bay to just barely inside Florida. So, any hybrids with a rubra-like parent from further east in Florida would most likely be with $S$. rubra subsp. gulfensis Schnell. In their 1956 paper on Sarracenia hybrids, Bell and Case mention on 
p. 146 under $S$. ×readii that they found hybrids also in Santa Rosa County, Florida, numbered Bell 1526 and Case P-42. These hybrids could now be given a new hybrid name as they are formed by a different species crossing with $S$. leucophylla. Therefore I designate a new hybrid between S. leucophylla and S. rubra subsp. gulfensis.

Sarracenia Xbellii Mellichamp hyb. nov.-TYPE: U.S.A. Florida. Santa Rosa, Co., west side of Hwy. 87, just north of Yellow River, Case P-42, ca. 1952. (HOLOTYPE: A cultivated leaf of this specimen has been seen, pressed, and deposited in UNCC, Mellichamp s.n. Sept. 9, 2008.)

Syn.: Sarracenia $\times$ readii sensu Bell non Bell, J. Elisha Mitchell Sci. Soc. 68: 69. 1952, p.p.

A S. ×readii foliis glabratis, longioribus usque ad $42 \mathrm{~cm}$ altis, venis plus numerosis differt.

Plants intermediate between Sarracenia leucophylla Raf. and S. rubra subsp. gulfensis, but especially differing from $S$. $\times$ readii in being consistently taller (to $42 \mathrm{~cm}$ ), and especially in having pitchers that are glabrous on the exterior, of thicker texture, and with more conspicuous red veins on the upper pitcher and hood, particularly the inner surface of the tube and on the hood. Also, the hood is usually longer than wide, $4 \times 3 \mathrm{~cm}$, and the edges of the hood curve upward while still being wavy. This is in contrast to typical $S$. ×readii where it is influenced by the $S$. alabamensis subsp. wherryi parent that has generally shorter pitchers that are consistently finely pubescent externally, flatter and less wavy-margined hoods, and much fewer veins on the inside of the tube and the terminal portions of the hood.

I have named this hybrid in honor of botanist Dr. Clyde Ritchie Bell, who produced a monograph of Sarraceniaceae in 1949 and, with F.W. Case, went on to compile data on most of the known wild hybrids in 1952 and 1956. This hybrid is rare, but should be sought where the narrow range of $S$. rubra subsp. gulfensis overlaps the wider range of $S$. leucophylla in the western Florida panhandle (Santa Rosa, Okaloosa, and Walton Counties) and just into adjacent Alabama in the Conecuh National Forest.

\section{Sarracenia $\times$ casei}

In a converse situation, Sarracenia $\times$ gilpinii Bell \& Case was named for a hybrid between S. psittacina and S. rubra from Santa Rosa Co., Florida, just north of the Yellow River where S. $\times$ bellii was found. Thus, its $S$. rubra parent is $S$. rubra subsp. gulfensis. Therefore, one can name the analogous hybrid of $S$. psittacina $\times S$. alabamensis subsp. wherryi as a different hybrid.

Sarracenia Xcasei Mellichamp hyb. nov. - TYPE: U.S.A. Alabama. Washington Co., along US 45 just north of Deer Park, 7 Aug. 1985. Mellichamp s.n. (HOLOTYPE: UNCC; ISOTYPE: $\mathrm{NCU})$.

Syn.: Sarracenia $\times$ gilpinii sensu Bell \& Case non Bell \& Case, J. Elisha Mitchell Sci. Soc. 72: 149. 1956, p.p.

\section{A S. × $\times$ ilpinii foliis molliore vestitis differt.}

Plants intermediate between Sarracenia psittacina Michaux and S. alabamensis subsp. wherryi, but especially differing in the outer surface of the pitcher being softly pubescent, a trait from the $S$. $a$. subsp. wherryi parent. The leaves on my specimen are only faintly hairy; but they are not thick textured like a hybrid with S. leucophylla or S. $r$. subsp. gulfensis would likely be. The leaves are ascending and do not have the globose head of $S$. psittacina. The hood is not at all undulate, so I rule out $S$. leucophylla as a parent. The flowering scape is much longer than the leaves, $35 \mathrm{~cm}$ in my specimen, and the flower is small, ruling out $S$. alata as a parent. This is a 
rare hybrid, mainly because $S$. psittacina flowers so late; but I have seen $S$. $a$. subsp. wherryi flowering at odd times, as late as the first of September.

I have named this interesting hybrid after botanist Frederick W. Case, who, with his late wife Roberta, studied pitcher plants for many decades in the Deep South, discovering many natural hybrids and formally recognizing $S$. alabamensis as a distinct species.

\section{Sarracenia $\times$ charlesmoorei}

The final new hybrid comes from the mountains of the Carolinas, and is similarly namable when one recognizes a hybrid involving $S$. purpurea, and $S$. jonesii Wherry as distinct from $S$. rubra Walter. The hybrid name $S$. $\times$ chelsonii Masters was published in 1877 as a cross between $S$. purpurea and S. rubra. Since that original plant came from Scotland Co. in eastern North Carolina, the one parent would have been S. rubra subsp. rubra.

Sarracenia Xcharlesmoorei Mellichamp hyb. nov.-TYPE: U.S.A. North Carolina, Henderson Co., 20 October 2007, Mellichamp s.n. (HOLOTYPE: UNCC; ISOTYPE: NCU).

Syn.: Sarracenia $\times$ chelsonii sensu Bell non Masters, J. Elisha Mitchell Sci. Soc. 68: 65. 1952, p.p.

A Sarracenia $\times$ chelsonii foliis $25-50 \mathrm{~cm}$ longis, tubo apicem versus dilatato, $6-15 \mathrm{~cm}$ longe petiolatis, scapo foliis parum longioribus differt.

Plants intermediate between $S$. purpurea subsp. purpurea and $S$. jonesii, showing hybrid vigor in the production of robust, tall pitchers of thick texture. Pitchers on flowering size plants $25-50 \mathrm{~cm}$ long, slightly curving upwards, somewhat enlarged in the upper $1 / 4$ th of the tube as influenced by $S$. jonesii, dark green with dark red suffusion above, with heavy dark red veins. Orifice to $3 \mathrm{~cm}$ wide, rim tightly rolled, dark red. Hoods erect, cordate, to $6-8 \mathrm{~cm}$ wide, slightly undulate, heavily veined. Wing $0.75-1.5 \mathrm{~cm}$ wide, prominent, widest below middle. The solid non-hollow petioles $8-20 \mathrm{~cm}$ long, $1 / 3$ or more the length of the leaves, as in S. jonesii. Sarracenia rubra has solid petioles less than 1/4th the length of the leaves. Flowering scapes somewhat longer than the leaves, as in S. jonesii, but not nearly twice as long as would be seen in $S$. rubra. Flowers and fruits slightly larger than $S$. jonesii, capsules to $1.5 \mathrm{~cm}$ wide.

These are magnificent hybrids (see Figures 3, 4), but are extremely rare as the habitats for $S$. jonesii are disappearing. The mountain bogs in flat depressions along streams are all but gone in the low mountains and steep escarpment where the two Carolinas meet, victims of development. The hillside seeps and water flows along majestic exposed rock surfaces on the south-facing Blue Ridge Escarpment south of Brevard, North Carolina are safer, but subject to droughtthere are several nature preserves there in South Carolina now. The long-famous type location for this newly described hybrid is just about the last of its kind, and struggles to survive, even under knowledgeable management by The Nature Conservancy.

I have named this remarkable hybrid after the late Mr. Charles F. Moore, a well-known naturalist from Brevard, North Carolina. He was a long-time friend who showed me many interesting plants in the mountains. He was most famous for his knowledge of Shortia galacifolia and Sarracenia jonesii. Since there is another hybrid named $S$. $\times$ mooreana $(S$. leucophylla $\times$ flava), from England in 1877, I have used the more recent Mr. Moore's full name.

This may seem to be an academic exercise to name-or rename-these hybrids, but it is necessary because the taxa recognized at the species level as being involved are distinctive, and have distinct ranges, and one can see their traits in the hybrids. I would encourage all who study Sarracenia to be watchful for these hybrids so that they may become better known. 


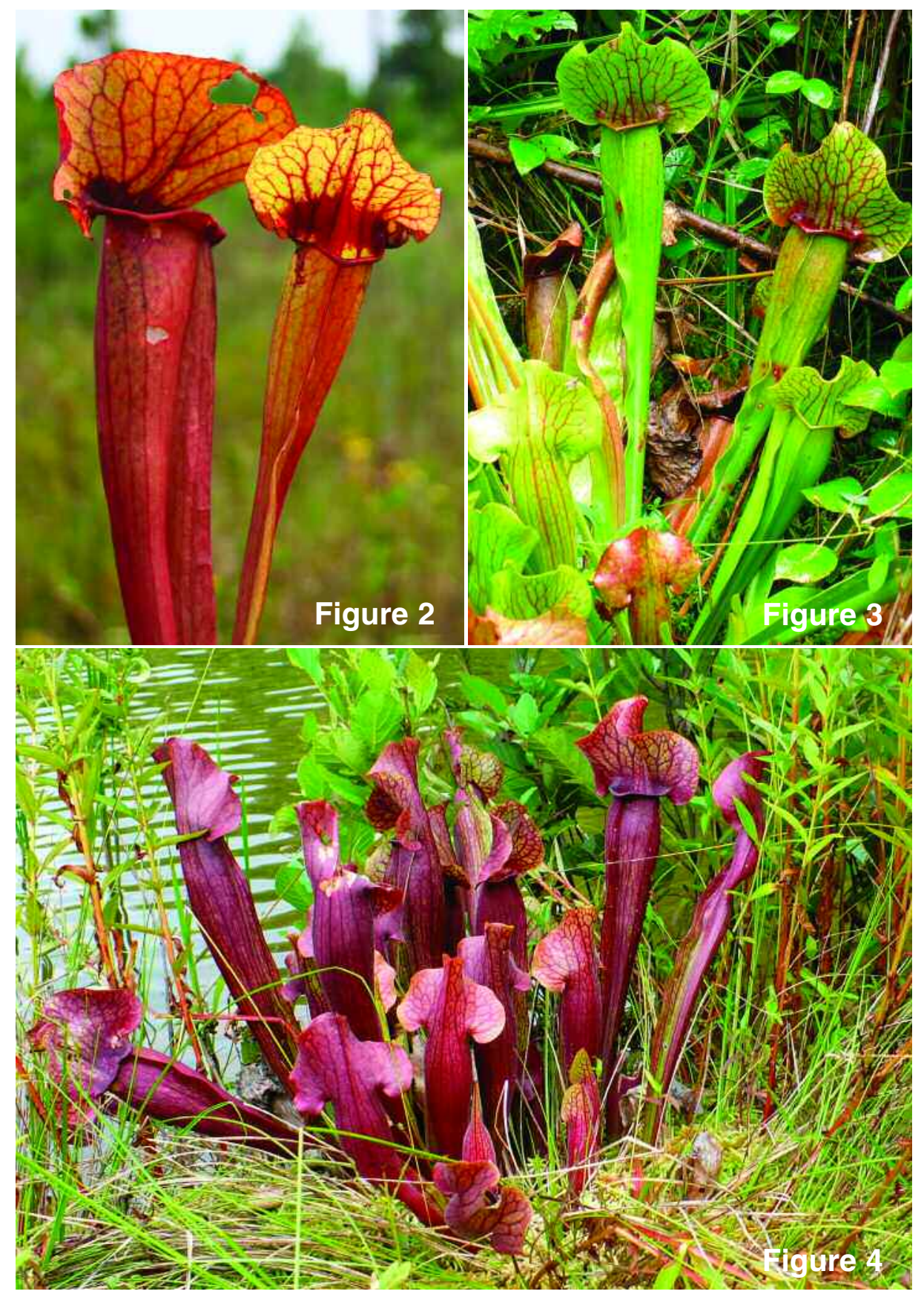

Figure 2: S. ×naczii type specimen: Escambia Co., Florida, 3 Sept. 2007.

Figure 3: S. $\times$ charlesmoorei at the North Carolina type location, 12 Aug. 2008.

Figure 4: $S$. $\times$ charlesmoorei, on small lake near Brevard, North Carolina.

Photos (figures 2-4) by T.L. Mellichamp. 
Acknowledgements: I would like to thank those who helped me in the study of Sarracenia hybrids: Ritchie Bell, who encouraged me by giving me my first scientific paper reprint (his 1952 hybrids paper); Steven Broyles, my excellent student field assistant in 1985; Fred Case, who introduced me to hybrids and the habits of Sarracenia; the late Rob Gardener of the North Carolina Botanical Garden with whom I traveled and made many horticultural hybrids; the late Charles Moore, who knew all the good sites around Brevard; Rob Naczi, who has talked with me for hours about Sarracenia; the late J.C. Moore, who knew all the good sites around Mobile; Stefan Ploszak, with whom I went to the Gulf Coast in 2007 and explored every spot; Donald Schnell, who knew all the good sites in the Green Swamp; and finally my wife Audrey-who would often go with me, but mostly she let me go-I love you all.

\section{References}

Bell, C.R. 1952. Natural hybrids in the genus Sarracenia: I. History, distribution, and taxonomy. J. Elisha Mitchell Sci. Soc. 68: 55-80. (An excellent introduction.)

Bell, C.R. and Case, F.W. 1956. Natural hybrids in the genus Sarracenia: II. Current notes on distribution. J. Elisha Mitchell Sci. Soc. 72: 142-152. (Many new discoveries)

Naczi, R.F.C., Soper, E.M., Case, F.W., and Case, R.B. 1999. Sarracenia rosea (Sarraceniaceae), a new species of pitcher plant from the southeastern United States. Sida 18(4): 1183-1206. (An excellent model for a taxonomic study, with many good references.)
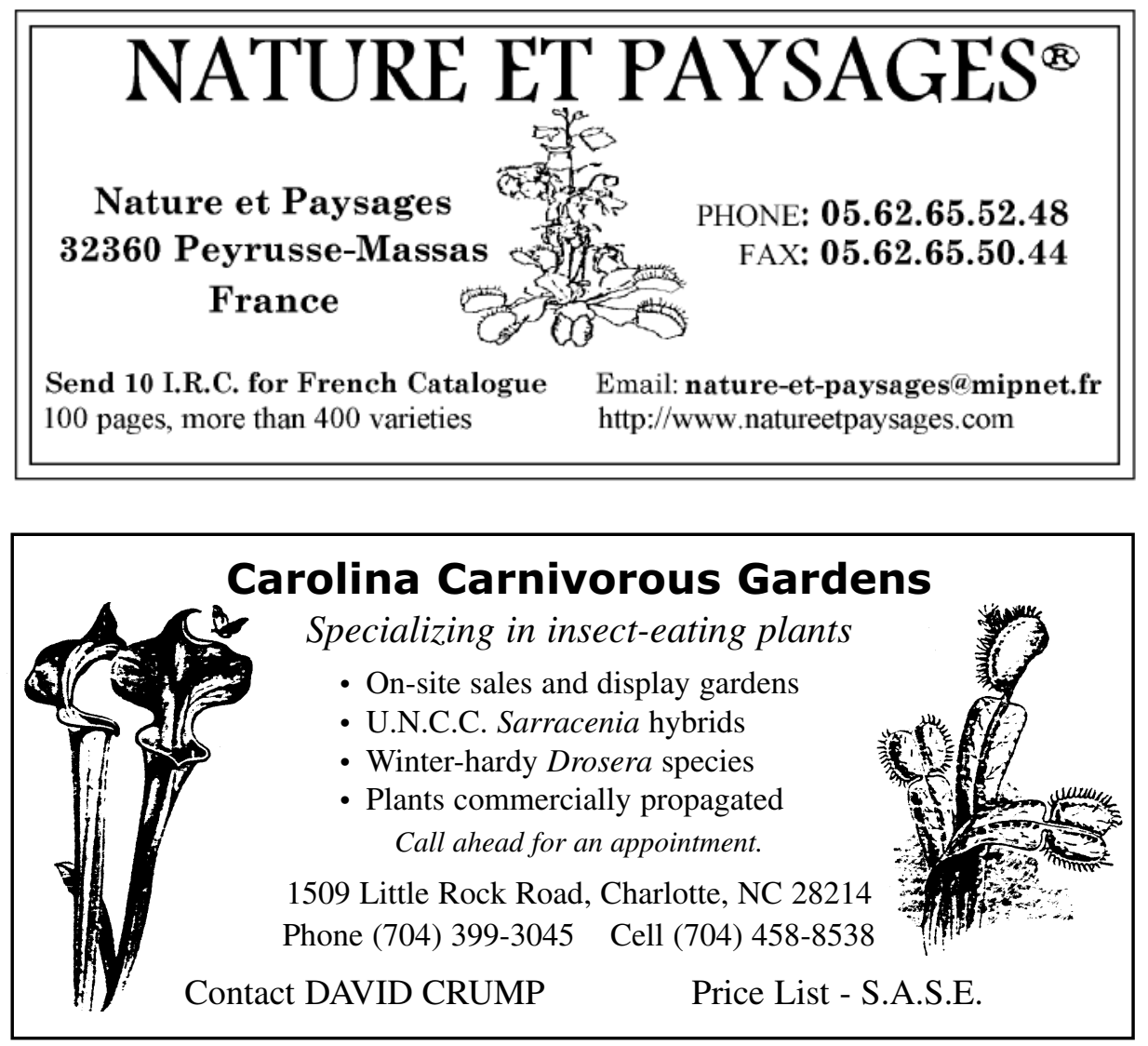